\title{
The phosphorus load and the variation of the trophic states of Cirata Reservoir (West Java, Indonesia) from 1988 to 2017
}

\author{
NIKEN T.M. PRATIWI", ZULHAMSYAH IMRAN, INNA PUSPA AYU, ALIATI ISWANTARI, \\ DWI YUNI WULANDARI \\ Department of Aquatic Resources Management, Faculty of Fisheries and Marine Sciences, Institut Pertanian Bogor. Jl. Agatis, Kampus IPB Darmaga, \\ Bogor 16680, West Java, Indonesia. Tel./fax.: +62-251-8622932, `email: niken_tmpratiwi@apps.ipb.ac.id
}

Manuscript received: 5 June 2020. Revision accepted: 18 August 2020.

\begin{abstract}
Pratiwi NTM, Imran Z, Ayu IP, Iswantari A, Wulandari DY. 2020. The phosphorus load and the variation of the trophic states of Cirata Reservoir (West Java, Indonesia) from 1988 to 2017. Biodiversitas 21: 4176-4183. Cirata Reservoir was constructed in 1987 between Saguling and Jatiluhur Reservoirs; these are the three man-made cascading lakes in West Java, Indonesia. Cirata Reservoir has been used for floating cage aquaculture activities. The high organic content from the remains of the fish pellets raised the phosphorus (P) load, resulting in the eutrophication of the reservoirs. This research was aimed to assess the P load and the variation of the trophic states of the reservoir from year 1988 to 2017. The trophic states and the nutrients' conditions of the water were determined using Myxophycean Index. Four groups of phytoplankton were found in the reservoir during observation: Cyanophyceae, Chlorophyceae, Bacillariophyceae, and Dinophyceae. In addition, one group was found in a smaller number of observations: Eugolenophyceae. Although the community structure of the phytoplankton has changed, the Cyanophyceae was always dominant in response against the condition of nutrients, especially P. The P load is closely related to the number of floating cages in the reservoir. This evidence showed that Cirata Reservoir tended to be relatively eutrophic. In general, despite that the P load tended to fluctuate, the trophic states of Cirata Reservoir remained dynamic in relatively high conditions; showed by the oligo-mesotrophic state during its first year of operation, then increased to eutrophic and hypertrophic by the next decade. Although the P load tended to decrease, it remains in the eutrophic condition in the recent time.
\end{abstract}

Keywords: Cascading reservoirs, Cirata Reservoir, eutrophication, floating cage

\section{INTRODUCTION}

Changes in water quality are influenced by various factors such as water use, onshore activities, design, and operation of water infrastructure (Choquette et al. 2019). Cirata Reservoir is one of cascading man-made lakes that was constructed in 1987 and located between Saguling and Jatiluhur Reservoirs, West Java, Indonesia. The reservoir has been used for numerous purposes, i.e. to operate hydropower plants, agricultural irrigations, and fisheries activities, both natural (catching), and culture (floating cage) fisheries that began in 1988 .

There is a strong connection between anthropogenic activities and water quality. High anthropogenic activities such as floating cage culture activity, runoff, and sediment erosion could result in excessive material input into the waters that could potentially lead to the eutrophication and the decrease of quality of the waters (McDowell and Hamilton 2013). The remains of the fish pellets in the operation of the floating cage will accumulate as organic matters that eventually will increase the nutrients in the reservoir waters. Excessive phosphorus $(\mathrm{P})$ concentration, as one of the elements for fish feed, is a major cause of eutrophication in freshwater lakes, reservoirs, and rivers (Maniagasi et al. 2013).

The dynamic of water quality serves as the main indicator of changes in trophic conditions. The second indicator is the change in the phytoplankton composition, as various phytoplankton in different compositions indicates respective trophic states of the associated waters. The presence of plankton may provide information about the conditions of the waters (Saragih and Erizka 2018). Waters dominated by Chlorophyceae and Bacillariophyceae belonged to mesotrophic level (Nedovic and Hollert 2005), while dominant Cyanophyceae with high density of green algae indicated eutrophic level (Ayoade et al. 2019).

The anthropogenic eutrophication also deteriorated the waters' functions. Abundant material input potentially resulted in exceedingly abundant nutrients. This would trigger phytoplankton bloom. As mentioned by Oliveira and Machado (2013), rich nitrogen or phosphorus content would blow the population of microalgae or phytoplankton out of proportion, especially those related to the increase in the phosphorus concentration. In general, naturally the nutrient would increase and the eutrophication eventually happened rather slowly in all water typologies. Further, however, the anthropogenic activities could accelerate the process. If material input could be suppressed, changes in water quality would not reach a level that interfere with the ecological processes in the aquatic ecosystem.

Combination of information about phytoplankton and water quality could substantiate the assessment of the trophic states of waters, especially those intervened by anthropogenic activities, such as Cirata Reservoir. 
Assessment of aquatic trophic status based on the presence of phytoplankton became more comprehensive if supported by information about nutrients in the waters (Krzebietke et al. 2013; Nayek et al. 2018).

Exploring aquatic biodiversity was also important to assess the bio-indicators of the waters' condition, particularly the trophic states of a lake, as reported by Rahman et al. (2016). Understanding the biotic key parameter would simplify the decision making on the aquatic ecosystem management, both control the eutrophication and restore the condition. Though many approaches can be used to assess the possibility of the increasing trophic level due to various input into the waters, starting from the low (Allinger and Reavie 2013; Shekha et al. 2017) and high (Qin et al. 2012; Opiyo at al. 2019), that would change the waters from oligotrophic to mesotrophic, eutrophic, or even hypertrophic; hence the biological approach such as Nygaard Index (Myxophycean Index in this term) was possible to be applied. This research aimed to assess the phosphorus (P) load and the variation of the trophic states of Cirata Reservoir from the first year of its operations (in 1988) until 2017.

\section{MATERIALS AND METHODS}

\section{Area of study}

This research was carried out in Cirata Reservoir waters, West Java, Indonesia which is geographically located at $6^{\circ} 44^{\prime} 14$ 'S and $107^{\circ} 17^{\prime} 56^{\prime \prime} \mathrm{E}$ (Figure 1). The reservoir is located between Saguling and Jatiluhur Reservoirs; these waters form cascading man-made lakes in the Citarum River system. Cirata Reservoir has been used for floating cage aquaculture activities that firstly began in 1988, i.e. when the reservoir had finished its final inundation.

\section{Procedures}

There were two data categories used in this study: primary and secondary. The primary data for phytoplankton and phosphorus $(\mathrm{P})$ were drawn from direct sampling in 1999, 2004, 2012, 2013, and 2017. The secondary data were obtained from various sources, both from published and unpublished sources such as a report, dissertation, thesis, and honorary thesis. The data of phytoplankton in 2012 and 2015 were obtained from nationally published article (Nurcahya and Nugraha 2013; Nurruhwati et al. 2017); while the data from 2005, 2006, and 2009 were obtained from Nuraini (2005), Zahidah (2006), Sudrajat et al. (2010). Not all of the secondary data provided complete information about the species names, rather they only mentioned the number of species in each class group of phytoplankton. Furthermore, for the phosphorus' secondary data from 2004 were obtained from Komarawidjaja et al. (2005), and the rest of the data were taken from 1988, 2002, 2005, 2006, 2009, 2014, 2015, 2016 from Sukimin (1995, 2003), Nuraini (2005), Mardiana (2007), Sudrajat et al. (2010), and BPWC/Cirata Reservoir Management Agency (2017), respectively. Therefore, data analysis was adjusted to the availability of data for providing a comprehensive representation of the studies that have been carried out over a relatively long period of time.
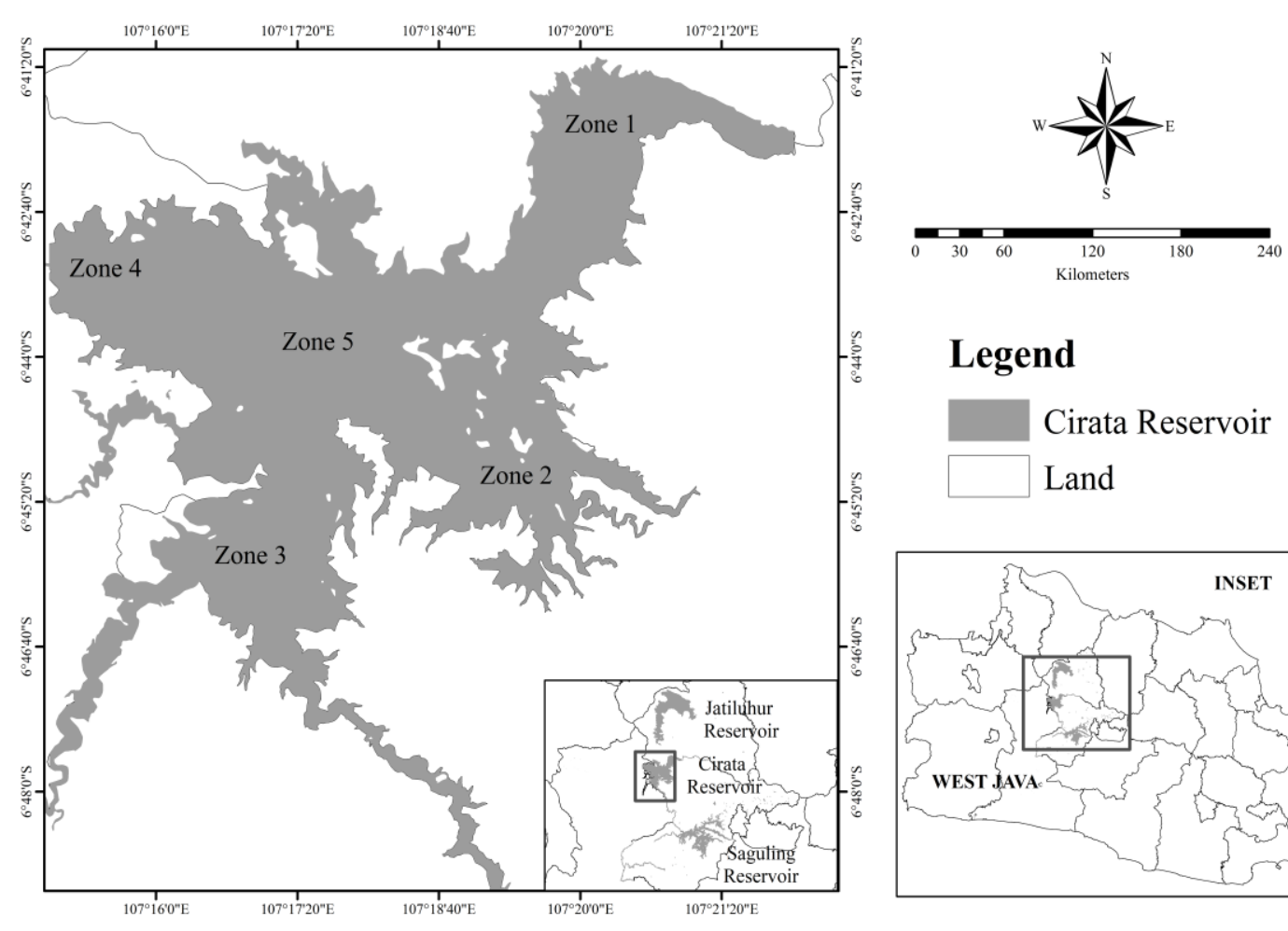

\section{Legend}
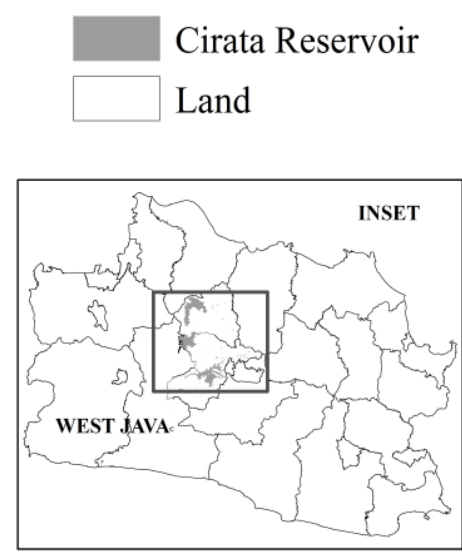

Figure 1. Cirata Reservoir, West Java, Indonesia 
Direct sampling was conducted twice per day, during daytime in the dry season. Generally, water samples were acquired from the five zones at the reservoir: the northern (Zone 1), eastern (Zone 2), southern (Zone 3), western (Zone 4), and center (Zone 5) of the reservoir, horizontally (Figure 1), in two layers, vertically (the surface and Secchi depth), and the samples were analyzed in the laboratory for phytoplankton species, phytoplankton abundance, and phosphorus. There are several guidelines available for phytoplankton identification and classification, such as Prescott (1970) and Mizuno (1979) in Pratiwi et al. (2019). The phosphorus analysis was carried out based on APHA (2012).

\section{Data analysis}

The trophic states of the waters were determined using Myxophycean Index, based on the presence of Cyanophyceae and Desmids species (Bellinger and Sigee 2010), and the nutrients' conditions (EPA 2000 in Tas 2012). The ratio of the numbers of eutrophication indicator phytoplankton species results in a value that indicates the trophic states; i.e. lower than 1 for oligotrophic and higher than 1 for eutrophic (Bellinger and Sigee 2010). Calculation of phosphorus load was conducted based on
PerMenLH (Decree of The Minister of Environment) No 28 Year 2009 about Total Maximum Load of the Lake or Reservoir. In addition, a regression analysis was also carried out (Mattjik and Sumertajaya 2002 in Pratiwi et al. 2019) to assess the relationship between the increasing number of floating cages and the phosphorus load.

\section{RESULTS AND DISCUSSION}

The overall result suggested a series of the trophic states of Cirata Reservoir based on the phytoplankton community structure and the phosphorus load. The common phytoplankton in the reservoir was Cyanophyceae, Chlorophyceae, Bacillariophyceae, Dinophyceae, and Euglenophyceae, and are shown in Table 1. Some species of intolerant indicators, such as Cosmarium, Euastrum, Micrasterias, and Staurastrum that indicate good water conditions (oligotrophic) were recorded. In contrast, the species of Cyanophyceae - as the tolerant indicators that usually dominate eutrophic or hypertrophic waters - were also found. The presence of those two groups will indicate the dynamic of trophic states of the waters of Cirata Reservoir.

Table 1. The phytoplankton in Cirata Reservoir, West Java, Indonesia from 1999 to 2017.

\begin{tabular}{|c|c|c|}
\hline Class & Year & Species \\
\hline \multicolumn{3}{|l|}{ Cyanophyceae } \\
\hline & 1999 & Anabaena sp., Oscillatoria sp. \\
\hline & 2004 & $\begin{array}{l}\text { Microcystis sp., Oscillatoria sp., Merismopedia sp., Aphanothece sp., Chroococcus sp., Phormidium sp., } \\
\text { Oscillatoria sp., Anabaena sp. }\end{array}$ \\
\hline & 2012 & Microcystis sp., Oscillatoria sp., Merismopedia sp., Aphanothece sp., Chroococcus sp., Phormidium sp. \\
\hline & 2013 & $\begin{array}{l}\text { Microcystis sp., Oscillatoria sp., Merismopedia sp., Aphanothece sp., Chroococcus sp., Phormidium sp., } \\
\text { Anabaena sp. }\end{array}$ \\
\hline & 2017 & Merismopedia sp., Oscillatoria sp., Microcystis sp., Phormidium sp., Anabaena sp. \\
\hline \multicolumn{3}{|r|}{ (2) } \\
\hline & 1999 & Chlorogonium sp., Cosmarium sp., Pediastrum sp., Staurastrum sp. \\
\hline & 2004 & $\begin{array}{l}\text { Micractinium sp., Micrasterias sp., Euastrum sp., Volvox sp., Ulothrix sp., Tetraspora sp., Tetraedron sp., } \\
\text { Staurastrum sp., Selenastrum sp., Scenedesmus sp., Pediastrum sp., Gleociystis sp., Chlorogonium sp., } \\
\text { Asterococcus sp., Actinastrum sp., Euastrum sp., Dictyosphaerium sp., Arthrodesmus sp. }\end{array}$ \\
\hline & 2012 & $\begin{array}{l}\text { Micractinium sp., Micrasterias sp., Euastrum sp., Volvox sp., Tetraspora sp., Tetraedron sp., Staurastrum } \\
\text { sp., Selenastrum sp., Scenedesmus sp., Pediastrum sp., Gloeocystis sp., Asterococcus sp., Actinastrum sp. }\end{array}$ \\
\hline & 2013 & $\begin{array}{l}\text { Micractinium sp., Micrasterias sp., Euastrum sp., Volvox sp., Tetraspora sp., Tetraedron sp., Staurastrum } \\
\text { sp., Selenastrum sp., Scenedesmus sp., Pediastrum sp., Botryococcus sp., Mougeotia sp., Dictyosphaerium } \\
\text { sp., Gleociystis sp., Asterococcus sp., Actinastrum sp. }\end{array}$ \\
\hline & 2017 & Pediastrum sp., Arthrodesmus sp., Botryococcus sp., Mougeotia sp., Dictyosphaerium sp., Actinastrum sp. \\
\hline \multicolumn{3}{|r|}{ 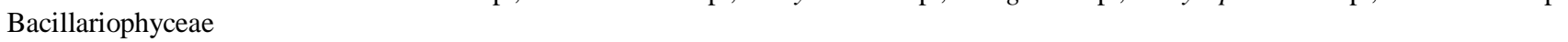 } \\
\hline & 1999 & Nitzschia sp., Synedra sp. \\
\hline & 2004 & Bacillaria sp., Cyclotella sp., Fragilaria sp., Melosira sp., Navicula sp., Nitzschia sp. \\
\hline & 2012 & $\begin{array}{l}\text { Bacillaria sp., Biddulphia sp., Coscinodiscus sp., Cyclotella sp., Cymbella sp., Fragilaria sp., Frustulia } \\
\text { sp., Melosira sp., Navicula sp., Nitzschia sp., Synedra sp. }\end{array}$ \\
\hline & 2013 & $\begin{array}{l}\text { Bacillaria sp., Biddulphia sp., Coscinodiscus sp., Cyclotella sp., Cymbella sp., Fragilaria sp., Frustulia } \\
\text { sp., Melosira sp., Navicula sp., Nitzschia sp., Synedra sp. }\end{array}$ \\
\hline & 2017 & Navicula sp., Nitzschia sp., Coscinodiscus sp., Melosira sp., Synedra sp. \\
\hline \multicolumn{3}{|r|}{ Fave } \\
\hline & 1999 & Peridinium sp., Ceratium sp. \\
\hline & 2012 & Peridinium sp., Ceratium sp. \\
\hline & 2017 & Peridinium sp., Ceratium sp. \\
\hline \multicolumn{3}{|l|}{ Euglenophyceae } \\
\hline & 2004 & Euglena sp. \\
\hline & 2009 & Phacus sp. \\
\hline
\end{tabular}


The composition, the total density of phytoplankton, and the most abundant group in Cirata Reservoir from 1999 to 2017 are presented in Figure 2. The number of species of the phytoplankton tended to vary temporarily. In total, the number of species varied from seven to 37 species, with the highest composition belonged to Chlorophyceae. On the other hand, although found in small number of species, the Cyanophyceae was found in a fairly high density from 1999 to 2017. The Cyanophyceae should have been taken into serious consideration as it indicated eutrophication, such as Oscillatoria sp. and Microcystis sp. that live in eutrophic waters as well as in the waters with high organic content (Robarts and Tamar 2010; Allinger and Reavie 2013; Ganai and Saltanat 2014; Kamilah et al. 2014).

The assessments based on the presence of the phytoplankton often needed to be supported by other bases, such as the presence of $\mathrm{P}$ (Paztaleniec and Poniewozik 2010; Nayek et al. 2018). The phosphorus total contains orthophosphate, which is the only form of phosphorus that can be assimilated by autotrophs (Nomosatyo and Lukman 2011; Novita MZ et al. 2015). The eutrophication is an increase in excess nutrients, leading to excessive production of autotrophs (Shekha et al. 2017), especially microalgae, including those from the class Cyanophyceae (Offem et al. 2011). As explained by Baho et al. (2017), high nutrients input would lead to a species' dominance. Naturally, nutrients input into the aquatic system through run-off, groundwater flow, atmospheric deposition (rain), and direct input from the terrestrial system (leaf litter) could affect the physical chemistry parameters of water (Hoverman and Johnson 2012). As found in Lake Lido, Bogor, West Java, Indonesia, as a response of high nutrients, the most abundant phytoplankton was Melosira sp., centric type of the Bacillariophyceae (Pratiwi et al. 2013). Phosphorus concentration could affect the growth of the freshwater diatoms (Bacillariophyceae class) whereas the decrease could lead to suboptimal growth (Katiyar et al. 2010).

The bloom of the emerging species indicated that the reservoir waters have been eutrophized (Molisani et al. 2010; Sayekti et al. 2015). The eutrophic state of reservoir water was also indicated by the community structure of the phytoplankton contained, such as the Cyanophyceae. The dominance of Cyanophyceae in Cirata Reservoir showed that the reservoir was in eutrophic conditions with high organic matter content. The abundance or the increase in Cyanophyceae indicated eutrophic water (Mu et al. 2014); and the biomass was greatly influenced by the changes of the excessive $\mathrm{P}$ concentration in the waters (Couture et al. 2018). Temporal variations, such as changes in the abundance and composition of phytoplankton, happened in response to the changes in the quality of the aquatic environment (Medupin 2011; Anggraini et al. 2016) and the trophic states (Ryan et al. 2006).

Specifically, based on the presence of Cyanophyceae and Desmids, the value of the Myxophycean Index of the reservoir waters, even in 1999, were categorized as mesoeutrophic level. It was increasingly eutrophic by the end of the observation period, with the highest level (hypertrophic) in 2015, and decreased during the last period of observation. Likewise, the concentration of total phosphorus was getting higher in 2002. The higher content of the total phosphorus also indicated a higher trophic state (Abell et al. 2010). The concentration of phosphorus began to exceed the threshold for eutrophic condition since 2002, reaching its highest value in 2004, and kept decreasing until the end of the observation period. Nevertheless, based on those two approaches, the decline still showed a high trophic status as eutrophic level, presented in Figure 3.

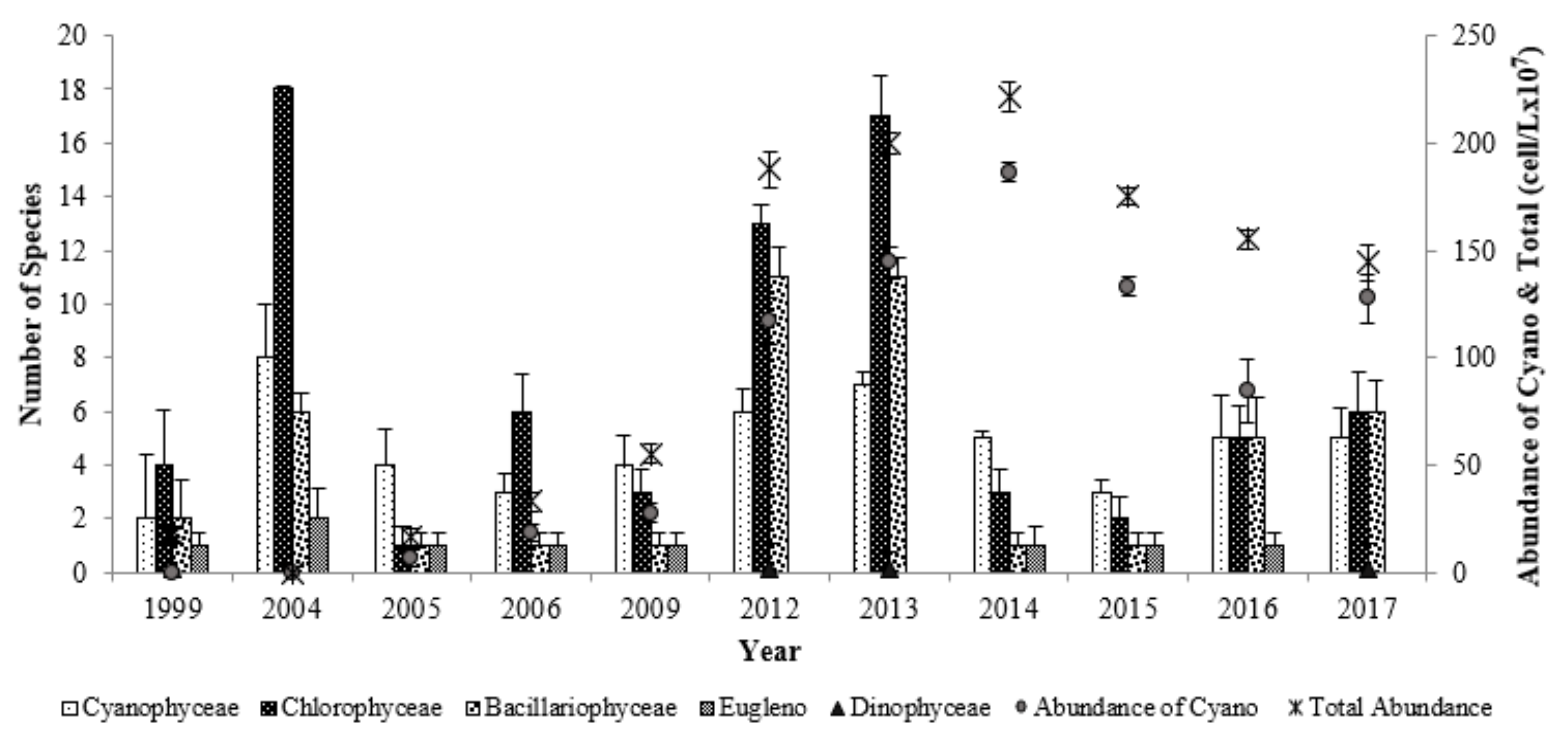

Figure 2. The temporal variation of the phytoplankton composition and density from 1999 to 2017 


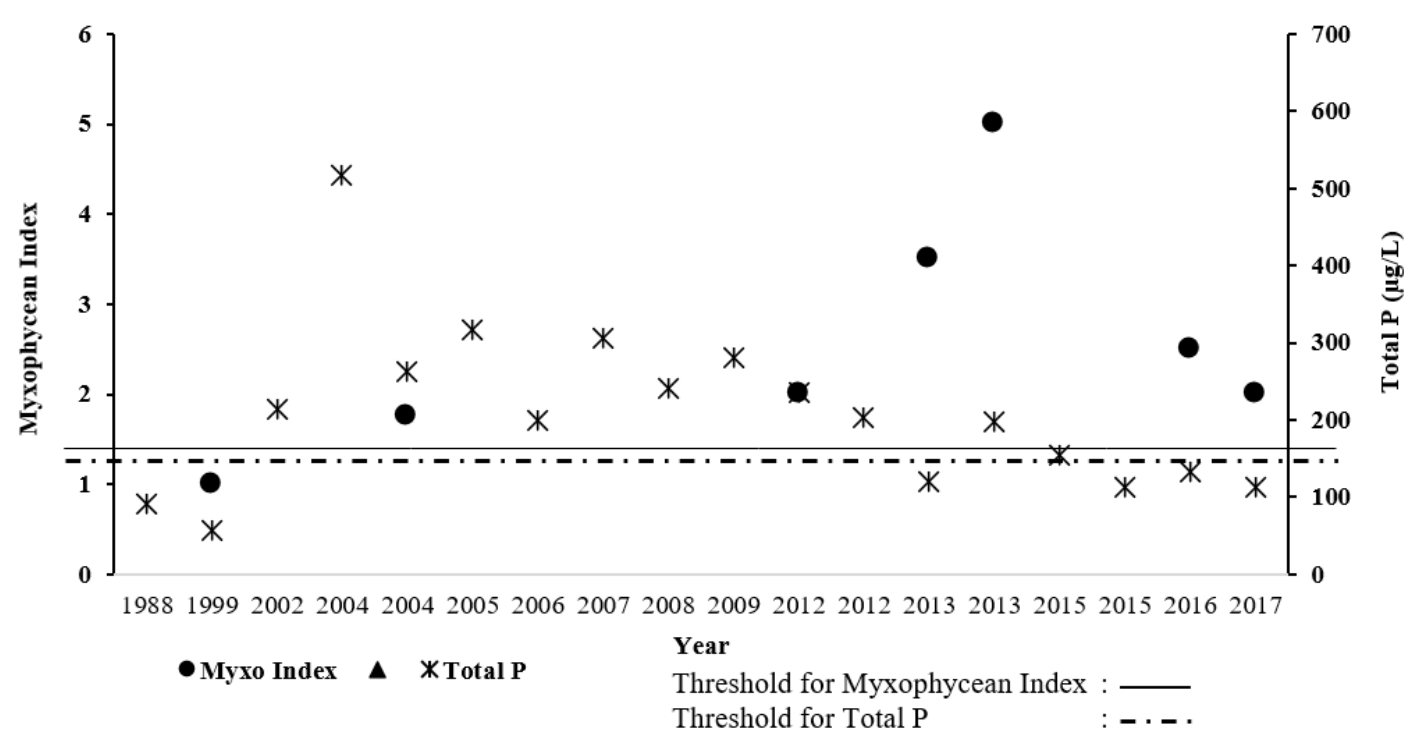

Figure 3. The trophic states of Cirata Reservoir, West Java, Indonesia based on Myxophycean Index and Total P (1988 to 2017)

The total P load in the waters were fluctuating (Figure 4). It increased sharply in the middle of the period, then decreased by the end of the observation period. These indicated that both the condition and the trophic states of the waters had changed. Cirata Reservoir had been in a relatively high eutrophic state since 2004 up to now.

Cirata Reservoir was filled completely and began to operate the hydropower plant in 1988. The reservoir has also been used for floating cage aquaculture activities with increasing number of operations. The change in $\mathrm{P}$ loads of Cirata Reservoir was related to the input of phosphorus, presumably from the floating cage culture activity. Based on EPA (2000) in Tas (2012), the phosphorus content in Cirata Reservoir indicated eutrophic to hypertrophic states. The nutrient had longer retention time in a deeper, more stratified reservoir waters (Lima et al. 2015). Organic matters from the rest of the feed accumulated and settled at the bottom. Even though there was some flushing process, the remaining feed from the floating cage activity was not completely wasted. In addition, the phytoplankton biomass in a reservoir mostly followed the hydrological pattern as well, based on the operation of the reservoir (Rangel et al. 2012).

The excess of $\mathrm{P}$, especially due to the operation of the floating cages, resulted in eutrophication. Specific description related to the relationship between the P load and the number of floating cages is illustrated in Figure 5. There appear two patterns of the relationship; the P load at low to moderate, and at moderate to high number of floating cages. The $\mathrm{P}$ load tended to increase when the number of floating cages were still relatively low. The opposite condition occurred in a high number of floating cages. This meant that at the beginning of the floating cage operating period (1988-2008), when water conditions were still relatively good and the oxygen was still high. In such conditions, dissolved $\mathrm{P}$ tended to precipitate. Therefore, the measured $\mathrm{P}$ in water had a pattern along with the increase of the floating cage operations.

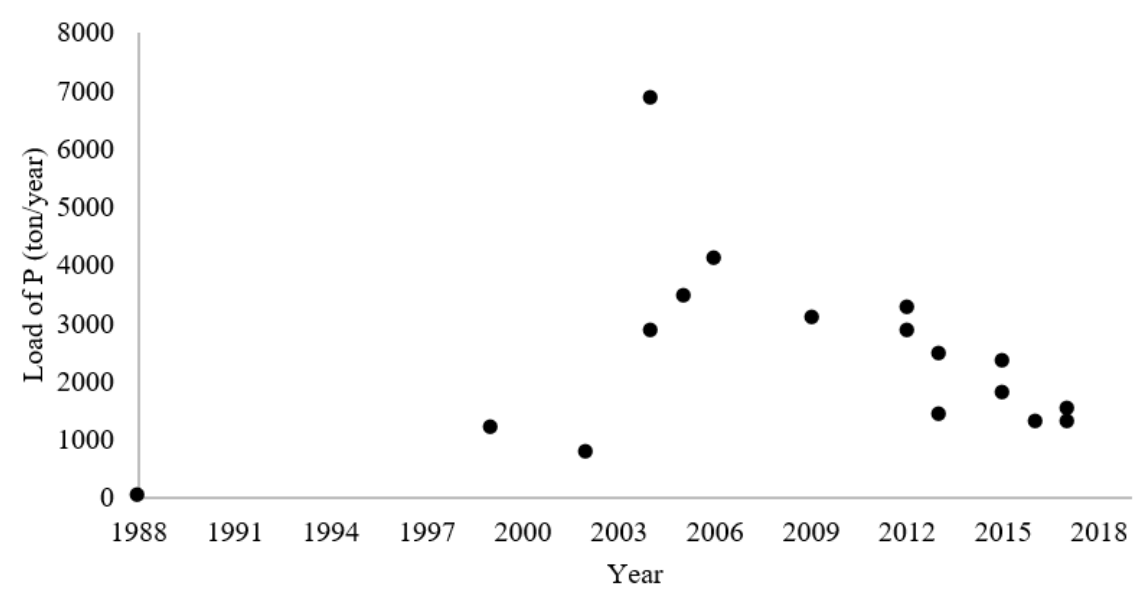

Figure 4. Loads of phosphorus in Cirata Reservoir, West Java, Indonesia from 1988 to 2017 


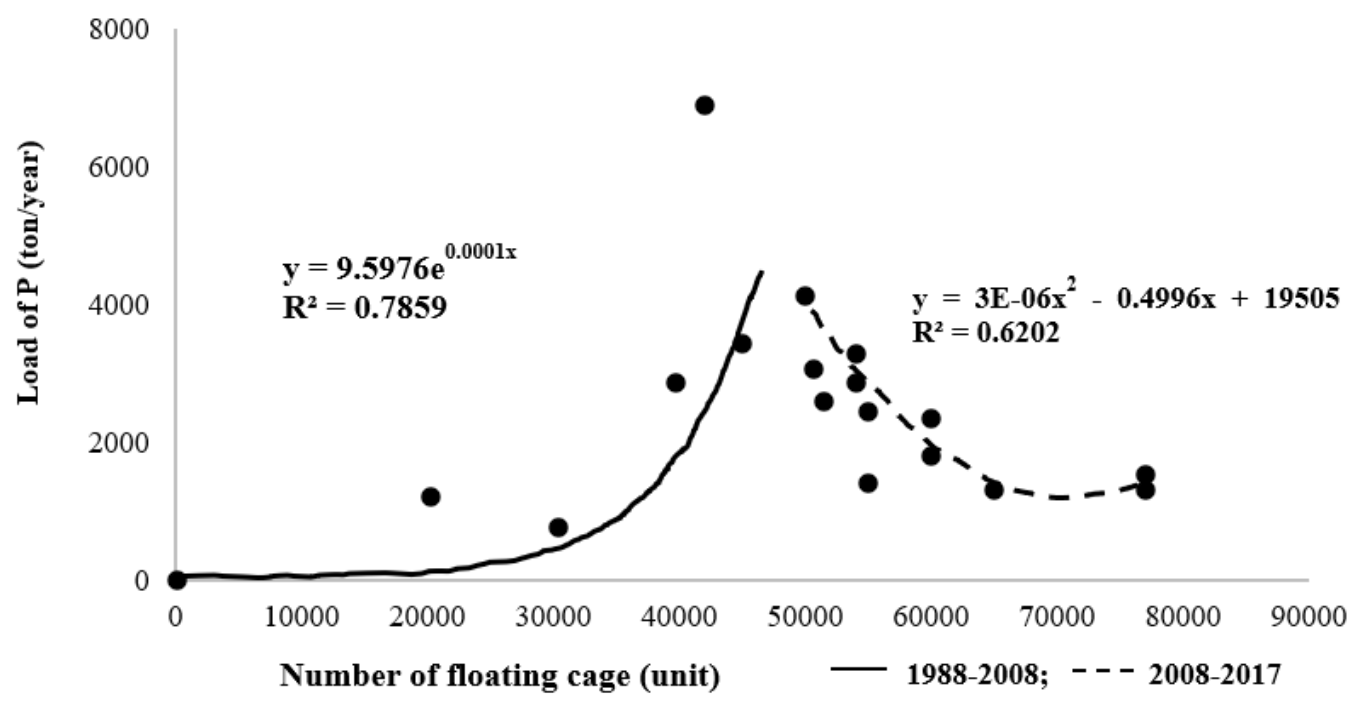

Figure 5. The number of floating cages and loads of phosphorus in Cirata Reservoir, West Java, Indonesia from 1988 to 2017

The result showed that the trophic states were different from the period when the floating cage operation had just begun, when the reservoir was still oligotrophic to mesotrophic. This indicated that, since the beginning of its operation in 1988, the reservoir waters has been receiving high material content. Currently, the nutrient concentration tended to decrease even number of activities and the production increases. However, the decrease in nutrients did not downgrade the trophic level of the waters; the water was still in eutrophic condition.

Different from non-point sources input that gave more dissolved-reactive phosphorus materials than the point sources (Baker et al. 2019), aquaculture activities as the point source input contributed to abundant organic matters from the remains of the feeds, thus potentially increased the nutrients. As shown in Figure 5, the high number of floating cages at the beginning of the observation resulted in a high $\mathrm{P}$ load. However, in the following years, the $\mathrm{P}$ load in the water column decreased as the $\mathrm{P}$ was already precipitated and deposited at the bottom of the waters. The results also showed the level of water saturation in accommodating the P load, as shown by the state of the water which was always in eutrophic conditions.

In normal conditions, the $\mathrm{N} / \mathrm{P}$ ratio was set as a reference for the changes in the composition of phytoplankton types. However, if the $\mathrm{P}$ content has exceeded the minimum requirement, the change in the ratio did not affect the overall species compositions, but instead, it was limited to the species composition of the Cyanophyceae group. In the waters with excessive $\mathrm{P}$ content, there would always be a Cyanophyceae dominance, as shown in Lake Toba (Rahman et al. 2016). In general, eutrophic waters have moderate to very poor ecological condition (Paztaleniec and Poniewozik 2010). This means that Cirata Reservoir waters had an imbalance in the ecological process which resulted in the disruption of aquatic productivity, which was indicated by the emergence of Cyanophyceae group dominance, instead of high species diversity. This was evident in the research results by Downing et al. (2001), de Hoyos et al. (2004), Molot et al. (2014), and Cottingham et al. (2015), in waters with high $\mathrm{P}$ content, Cyanophyceae dominance increased as $\mathrm{P}$ content rose.

When an ecosystem receives a relatively high concentration of nutrients input over a long period of time, the balance of the plankton community will be affected and the overall ecological process in the aquatic ecosystem will be disturbed (Melo et al. 2018). Reservoir with such changing conditions triggered a decrease in water quality, which then followed up by a reduction in the potential use of the aquatic ecosystems. Furthermore, the blooms of the eutrophication indicator species and the operation of reservoir must be managed properly (Molisani et al. 2010; Sayekti et al. 2015).

The high concentration of the nutrient in the reservoir was caused by the feeding activities from the floating cage aquaculture. The floating cage activities contributed to nutrient loads in higher concentrations than the agriculture and domestic activities (Purnamaningtyas and Tjahjo 2008). The high loads of nutrients affected the water quality of Cirata Reservoir. The same conditions were also found in other waters with floating cage activities, such as Jatiluhur Reservoir (Putri and Purnamaningtyas 2013), Lake Lido (Pratiwi et al. 2013), and Lake Toba (Rahman et al. 2016; Pratiwi et al. 2017). The material inputs in those lakes generally came from floating cage activities. These high nutrient load increases, due to uncontrolled floating cage activities, disrupted the reservoir functions. As a result, the sustainability level of the reservoir function became relatively low (Qin et al. 2012; Kholil et al. 2015).

It was highly recommended to measure and manage total $\mathrm{P}$ input in all aquatic ecosystems (Lihawa and Mahmud 2017); the manager of the reservoir was recommended to pay attention to the potential input of phosphorus loads from the materials input. By limiting the P load below the permitted threshold, the potential 
eutrophication could be mitigated (Jimenez-Martinez 2020). One of the recommendations was to decrease loads of $\mathrm{P}$ in Cirata Reservoir, and introduced milkfish to eat phosphorus-assimilating phytoplankton (Warsa et al. 2018). This recommendation was based on the successful achievement in Jatiluhur Reservoir that managed to improve the water quality by introducing milkfish (Tjahjo et al. 2011).

In conclusion, both of the P load and the trophic states of Cirata Reservoir were deemed to be dynamic. Although the P load showed gradual decrease, the trophic states of the reservoir remained dynamic in relatively high conditions; an oligo-mesotrophic state during the first year of its operation, increased to eutrophic and hypertrophic within the next decade, and then declined to eutrophic. In general, this research suggested that serious attention must be paid to maintain the function of the aquatic ecosystem of Cirata Reservoir.

\section{ACKNOWLEDGEMENTS}

This research was funded by the Ministry of Research, Technology and Higher Education of The Republic of Indonesia. We are extremely grateful to B. Marhaeni, A. Baksir, S. Sukimin, A.J. Lelono, I. Jubaedah, S. Handayani, T.H. Prihadi, D. Nuraini, Zahidah, L. Mardiana, I. Insan, M.R.A. Putri, S.E. Purnamaningtyas, P. Nurlailudin, I. Rustikawati, NB Soegesti, SEAMEO-BIOTROP, BPPKP or Marine and Fisheries Research and Development Agency, and the BPWC or Cirata Reservoir Management Agency for all their contributions in this research.

\section{REFERENCES}

Abell JM, Özkundakci D, Hamilton DP. 2010. Nitrogen and phosphorus limitation of phytoplankton growth in New Zealand lakes: implications for eutrophication control. Ecosystems 13: 966-977.

Allinger LE, Reavie ED. 2013. The ecological history of Lake Erie as recorded by the phytoplankton community. J Gt Lakes Res 39: 365 382 .

Anggraini A, Sudarsono, Sukiya. 2016. Plankton abundance and trophic level in River Bedog. Jurnal Biologi 5: 1-11. [Indonesian]

APHA [American Public Health Association]. 2012. Standard Method for the Examination of Water and Wastewater, $22^{\text {nd }}$ ed., edited by Rice EW, Baird RB, Eaton AD, Clesceri LS. American Public Health Association/American Water Works Association/Water Environment Federation, Washington.

Ayoade AA, Osuala BO, Adedapo TA. 2019. Physico-chemical parameters, chlorophyll a and phytoplankton community as trophic state indices of two tropical lakes, southwestern Nigeria. Eurasia J Biosci 13: 1-8.

Baho DL, Drakare S, Johnson RK, Allen CR, Angeler DG. 2017. Is the impact of eutrophication on phytoplankton diversity dependent on lake volume/ecosystem size? J Limnology 76(1): 199-210.

Baker DB, Johnson LT, Confesor Jr RB, Crumrine JP, Guo T, Manning NF. 2019. Needed: Early-term adjustments for Lake Erie phosphorus target loads to address western basin cyanobacterial blooms. J G Lakes Res 45: 203-211.

Bellinger EG, Sigee DC. 2010. Freshwater Algae: Identification and Use as Bioindicators. John Wiley and Sons Ltd, Oxford.

BPWC [Badan Pengelola Waduk Cirata/Cirata Reservoir Management Agency]. 2017. Technical Report: Monitoring of Water Quality and Trophic Level of Cirata Reservoir, 2011-2017, Cirata Reservoir Management Agency, Bandung Barat.
Choquette AF, Hirsch RM, Murphy JC, Johnson LT, Confesor Jr RB. 2019. Tracking changes in nutrient delivery to western Lake Erie: Approaches to compensate for variability and trends in streamflow. J Gt Lakes Res 45(1): 21-39.

Cottingham KL, Ewing HA, Greer ML, Carey CC, Weathers WC. 2015. Cyanobacteria as biological drivers of lake nitrogen and phosphorus cycling. Ecosphere 6(1): 1-19.

Couture R-M, Jannicke MS, Lin Y, Kaste $\varnothing$, Haande S, Solheim AL. 2018. Simulating water quality and ecological status of Lake Vansjø, Norway, under land-use and climate change by linking processoriented models with a Bayesian network. Sci Total Environ 621: 713-724.

de Hoyos C, Negro AI, Aldasoro JJ. 2004. Cyanobacteria distribution and abundance in the Spanish water reservoirs during thermal stratification. Limnetica 23(1-2): 119-132.

Downing JA, Watson SB, McCauley E. 2001. Predicting cyanobacteria dominance in lakes. Can J Fish Aquat Sci 58: 1905-1908.

Ganai AH, Saltanat P. 2014. Effect of physicochemical conditions on the structure and composition of the phytoplankton community in Wular Lake at Lankrishipora, Kashmir. Biodivers Conserv 6: 71-84.

Hoverman JT, Johnson PTJ. 2012. Ponds and lakes: a journey through the life aquatic. Nat Educ Knowl 3: 17.

Jimenez-Martinez, M. 2020. Fatigue of offshore structures: A review of statistical fatigue damage assessment for stochastic loadings. Int $\mathrm{J}$ Fatigue 132(105327): 1-17.

Kamilah F, Rachmawati F, Indah NK. 2014. Diversity of plankton that is tolerant to polluted waters in sulfur springs, Sumber Beceng Sumenep, Madura. LenteraBio 3: 226-231. [Indonesian]

Katiyar D, Lall AM, Singh B. 2010. Effect of phosphate on growth of diatoms. Indian J Sci Res 1: 103-106.

Kholil, Dharoko TA, Widayati A. 2015. Multi-dimensional scaling approach for evaluating the sustainability of Cirata Reservoir - West Java Province. J Manusia dan Lingkungan 22(1): 22-31. [Indonesian]

Komarawidjaja W, Sukimin S, Arman E. 2005. Cirata reservoir water quality status and its impact on the growth of cultured fish. J Tek Ling P3TL-BPPT 6(1): 268-273. [Indonesian]

Krzebietke AN, Stawecki K, Pyka JP, Hutorowicz J, Zdanowski B. 2013. Phytoplankton in relation to water quality of a mesotrophic lake. Pol J Environ Stud 22(3): 793-800.

Lihawa F, Mahmud M. 2017. Evaluation of water quality characteristics of Lake Limboto. Jurnal Pengelolaan Sumberdaya Alam dan Lingkungan 7: 260-266. [Indonesian]

Lima PF, Sousa MSR, Porfírio A F, Almeida BS, Freire RHF, Santaella ST. 2015. Preliminary analysis on the use of Trophic State Indexes in a Brazilian semiarid reservoir. Acta Sci Biol Sci 37(3): 309-318.

Maniagasi R, Tumembouw SS, Mundeng Y. 2013. Analysis of physicalchemical quality of waters at aquaculture area in Lake Tondano, North Sulawesi Province. Budidaya Perairan 1: 29-37. [Indonesian]

Mardiana L. 2007. Study of Phosphorus Content in Water and Sediment Influenced by Floating Net Cage Activity in Cirata Reservoir, West Java. [Thesis]. IPB University, Bogor. [Indonesian]

McDowell RW, Hamilton DP. 2013. Nutrients and eutrophication: introduction. Mar Freshw Res 64: iii-vi.

Medupin C. 2011. Phytoplankton community and their impact on water quality: an analysis of Hollingsworth lake UK. J Appl Sci Environ Manage 15: 347-350.

Melo TX, Dias JD, Simo es NR, Bonecker CC. 2018. Effects of nutrient enrichment on primary and secondary productivity in a subtropical floodplain system: an experimental approach. Hydrobiologia 827: 171-181.

Molisani MM, Sousa BH, Becker H, Moreira MOP, Hijo CAG, de Monte TM, Vasconcellos GH. 2010. Trophic state, phytoplankton assemblages and limnological diagnosis of the Castanhao Reservoir, CE, Brazil. Acta Limnol Bras 22(1): 1-12.

Molot LA, Watson SB, Creed IF, Trick CG, Mc Cabe SK, Verschoor MJ, Sorichetti RJ, Powe C, Venkiteswaran JJ, Schiff SL. 2014. A novel model for cyanobacteria bloom formation: the critical role of anoxia and ferrous iron. Freshw Biology 59: 1323-1340.

Mu X, Wang F, Sun H, Chu L, Wang J. 2014. Characteristics of phytoplankton community structure and evaluation of trophic state of water body in Bosten Lake. Advanced Materials Res 864-867: 422427.

Nayek S, Gupta S, Pobi KK. 2018. Physicochemical characteristics and trophic state evaluation of post-glacial mountain lake using multivariate analysis. Global J Environ Sci Manage 4(4): 451-464. 
Nedovic JR, Hollert H. 2005. Phytoplankton community and chlorophyll a as Trophic State Indices of Lake Skadar (Montenegro, Balkan). Environ Sci Pollut Res 12: 146-152.

Nomosatyo S, Lukman. 2011. The availability of nitrogen (N) and phosphorus (P) nutrients in the waters of Lake Toba, North Sumatera. Limnotek 19: 127-137. [Indonesian]

Novita MZ, Soewardi K, Pratiwi NTM. 2015. Determination of lake carrying capacity for natural fisheries (Case study: Lake Cilala, Bogor Regency). Jurnal Ilmu Pertanian Indonesia 20(1): 66-71. [Indonesian]

Nuraini D. 2005. Effect of Substrate on Periphyton Growth in Cirata Reservoir, West Java. [Hon. Thesis]. IPB University, Bogor. [Indonesian]

Nurcahya Y, Nugraha Y. 2013. Phytoplankton abundance and composition in Cirata Reservoir, West Java. Buletin Teknik Litkayasa Sumber Daya dan Penangkapan 11(1): 37-43. [Indonesian]

Nurruhwati I, Zahidah, Sahidin A. 2017. Plankton abundance at Cirata Reservoir West Java Province. Jurnal Akuatika Indonesia 2(2): 102 108. [Indonesian]

Offem BO, Ayotunde EO, Ikpi GU, Ada FB, Ochang SN. 2011. Planktonbased assessment of the trophic state of three tropical lakes. J Environ Prot 2(3): 304-315.

Oliveira M, Machado AV. 2013. The role of phosphorus on eutrophication: a historical review and future perspectives. J Environmental Technology Rev 2(1): 117-127.

Opiyo SB, Getabu AM, Sitoki LM, Shitandi A, Ogendi GM. 2019 Application of the Carlson's Trophic State Index for the assessment of trophic status of Lake Simbi ecosystem, a deep alkaline-saline lake in Kenya. Int J Fish Aquac Stud 7(4): 327-333.

[PerMenLH] Decree of The Minister of Environment No 28 Year 2009 about Total Maximum Load of the Lake or Reservoir. [Indonesian]

Paztaleniec A, Poniewozik M. 2010. Phytoplankton based assessment of the ecological status of four shallow lakes (Eastern Poland) according to Water Framework Directive - a comparison of approaches. Limologica 40: 251-259.

Pratiwi NTM, Hariadi S, Ayu IP, Iswantari A, Amalia FJ. 2013. Phytoplankton composition and trophic states of Lake Lido, BogorWest Java through several approaches. Jurnal Biologi Indonesia 9(1): 111-120. [Indonesian]

Pratiwi NTM, Rahman A, Hariyadi S, Ayu IP, Iswantari A. 2017. Relationship between trophic states and nutrients load in waters surrounding Samosir Island, Lake Toba, North Sumatera. In: Maghfiroh M, Dianto A, et al (eds) Lake Ecosystem Health and Its Resilience: Diversity and Risks of Extinction; Proceedings of the $16^{\text {th }}$ World Lake Conference. Research Center for Limnology, Indonesian Institute of Sciences, Cibinong, Indonesian.

Pratiwi NTM, Wardiatno Y, Azizi W, Iswantari A. 2019. Aufwuch community on association to aquatic plant in Lake Tempe, South Sulawesi. In: Sugardjito J, Garniati L, et al (eds) The 2018 International Conference on Biosphere Reserve: The Role of Stakeholders in Mainstreaming Natural Resources Related to Agenda 2030 (Sustainable Development Goals). IOP Conference Series: Earth and Environmental Science Volume 298 012004, Palembang, Indonesia.

Purnamaningtyas SE, Tjahjo DWH. 2008. Observation of water quality to support fisheries activity in Cirata Reservoir, West Java. J Lit Perikanan Ind 14(2): 173-180. [Indonesian]
Putri MRA, SE Purnamaningtyas. 2013. Variation of phytoplankton abundance in the area of floating net cages (KJA) of Jatiluhur Reservoir. Widyariset 16: 349-360. [Indonesian]

Qin BQ, Gao G, Zhu G, Zhang Y, Song Y, Tang X, Xu H, Deng J. 2012. Lake eutrophication and its ecosystem response. Chinese Sci Bull 58: 961-970.

Rahman A, Pratiwi NTM, Hariyadi S. 2016. Phytoplankton community structure in Lake Toba, North Sumatra. Jurnal Ilmu Pertanian Indonesia 21: 120-127. [Indonesian]

Rangel LM, Silva LHS, Rosa P, Roland F, Huszar VLM. 2012. Phytoplankton biomass is mainly controlled by hydrology and phosphorus concentrations in tropical hydroelectric reservoirs. Hydrobiologia 693: 13-28

Robarts RD, Tamar Z. 2010. Temperature effects on photosynthetic capacity, respiration, and growth rates of blooms-forming cyanobacteria. J Mar Freshw Res 21: 391-399.

Ryan EF, Duggan IC, Hamilton DP, Burger DF. 2006. Phytoplankton assemblages in North Island lakes of New Zealand: is trophic state, mixing, or light climate more important? New Zealand J Mar Freshw Res 40(3): 389-398.

Saragih GM, Erizka W. 2018. Phytoplankton diversity as an indicator of Lake Sipin water quality in Jambi City. Daur Lingkung 1: 22-28. [Indonesian]

Sayekti RW, Yuliani E, Bisri M, Juwono P, Prasetyorini L, Sonia F, Putri AP. 2015. Evaluation study of water quality and trophic states of Selorejo Reservoir due to the eruption of Mount Kelud for aquaculture. Jurnal Teknik Pengairan 6: 133-145. [Indonesian]

Shekha YA, Ali LA, Toma JJ. 2017. Assessment of water quality and trophic status of Duhok Lake Dam. Baghdad Sci J 14(2): 335-342.

Sudrajat A, Supriyadi H, Saputra A. 2010. Evaluation of Cirata Reservoir Waters as Aquaculture Area to Support the Increased of Food Security [Report]. Marine and Fisheries Research and Development Agency, Center for Aquaculture Research and Development, Jakarta. [Indonesian]

Sukimin S. 1995. Study of Floating Net Fisheries in Saguling and Cirata Reservoir: Impacts and Carrying Capacity of Waters. Research Report of Open Aquatic Biology Program, SEAMEO-BIOTROP, Bogor. [Indonesian]

Sukimin S. 2003. Results Report of Water Quality Monitoring of Cirata Reservoir Quarter III Year 2003. PT. Pembangkit Jawa-Bali, Cirata Reservoir Management Agency, Bandung. [Indonesian]

Tas B. 2012. Diversity of phytoplankton and trophic status in the Gaga Lake, Turkey. EES Technology Part A: Energy Sci Res 30(1): 33-44.

Tjahjo DWH, SE Purnamaningtyas, ES Kartamihardja. 2011. Evaluation of the success of milkfish (Chanos chanos) stocking in Ir. H. Djuanda Reservoir. Bawal 3(4): 231-237. [Indonesian]

Warsa A, J Hariyadi, LP Astuti. 2018. Mitigation of phosphorus load from aquaculture activities by stocking milkfish (Chanos chanos) in Cirata Reservoir, West Java. Jurnal Teknologi Lingkungan 19(2): 259-266. [Indonesian]

Zahidah. 2006. Phytoplankton Dynamics in Cirata Reservoir in Relation to Aquatic Primary Productivity. [Dissertation]. Padjajaran University, Bandung. [Indonesian] 